\title{
Validation of a preeclampsia early screening test in a Mexican population
}

Héctor Oviedo-Cruz, ${ }^{*}$ Erika R. Carrasco-Blancas ${ }^{1}$ and Marco A. Cortes-Martínez²

${ }^{1}$ Department of Maternal-Fetal Medicine, Medical Center for Specialized Fetal Care, Hospital Español de México; ${ }^{2}$ Department of Biochemistry and Quality, Laboratorio CEMAFE S.A. de C.V. Mexico City, Mexico

\begin{abstract}
Background: No preeclampsia screening test has been validated in our country. Objective: To assess the fit and performance of the FMF 4.0 Bayesian algorithm in a Mexican population. Method: Cohort study in singleton pregnancies, according to the competing risks model for preeclampsia. A priori risk was calculated based on medical history. Mean blood pressure (MBP), uterine artery mean pulsatility index (UtAmPI) and pregnancy-associated plasma protein A (PAPP-A) were measured at 1114 weeks of gestation using standardized methodology. The value of each marker was transformed into multiples of the median (MoM) by the original ${ }_{a}$ algorithm and by population-correction. ${ }_{b}$. Multivariate normal distribution and Bayes theorem were applied to obtain post-test probabilities. Results: There was 5.0\% (40/807) of preeclampsia. Distributions in women without preeclampsia were MBP $=0.927_{a}$ vs. $0.991_{b}, \mathrm{UtAmPI}=0.895_{a}$ vs. $1.030_{b}$ and PAPP-A $=0.815_{a}$ vs. $0.963_{b}(p<0.001)$. The AUC was $0.821_{a}$ vs. $0.823_{b}$. For a detection rate of $69 \%$, cutoff points were 1 in $240_{a}$ and 1 in $120_{b}$, with false positive rates of $31 \%$ and $29 \%$. Conclusions: The model has to be adjusted to the target population.
\end{abstract}

KEY WORDS: Preeclampsia. Maternal serum screening tests. Doppler ultrasonography. Blood pressure. Prenatal care. Mexico.

\section{Validación de un tamiz precoz de preeclampsia en una población mexicana}

\section{Resumen}

Antecedentes: Ninguna prueba de tamiz de preeclampsia ha sido validada en nuestro país. Objetivo: Evaluar el ajuste y rendimiento del algoritmo bayesiano FMF 4.0 en una población mexicana. Método: Estudio de cohorte en embarazos de feto único, según el modelo de riesgos en competencia para preeclampsia. El riesgo a priori se calculó por historia clínica. La presión arterial media (PAM), el índice de pulsatilidad medio de la arteria uterina (IPmAUt) y la proteína plasmática $A$ asociada al embarazo (PAPP-A) se midieron a las 11-14 semanas de gestación con metodología estandarizada. El valor de cada marcador se transformó en múltiplos de la mediana (MoM) por el algoritmo original ${ }_{a}$ y el corregido a a la población. Se aplicaron la distribución normal multivariante y el teorema de Bayes para las probabilidades posprueba. Resultados: Hubo un 5.0\% (40/807) de preeclampsia. Las distribuciones sin preeclampsia fueron PAM $0.927_{a}$ vs. $0.991_{b}$, UtAmPI $0.895_{a}$ vs. $1.030_{b}$ y PAPP-A $0.815_{a}$ vs. $0.963_{b}(p<0.001)$. El área bajo la curva fue $0.821_{a}$ vs. $0.823_{b^{*}}$. Para una detección del $69 \%$, los puntos de corte fueron 1 en $240_{a}$ y 1 en $120_{b}$, a falsos positivos del $31 \%_{a}$ y $29 \%$. Conclusiones: El modelo debe ajustarse a la población diana.

PALABRAS CLAVE: Preeclampsia. Pruebas de tamiz en suero materno. Ecografía Doppler. Presión arterial. Control prenatal. México. 


\section{Introduction}

Preeclampsia affects $2-8 \%$ of pregnancies in the world and is the main cause of both maternal and perinatal morbidity and mortality. ${ }^{1}$ In Mexico, it is a cause of maternal death despite regular prenatal care. ${ }^{2}$ Low doses of aspirin started at 16 weeks of gestation or earlier are an efficacious prophylaxis in high-risk pregnancies. ${ }^{3}$ Given that coverage by medical history is low, ${ }^{4}$ multiple marker tests were developed,,$^{5-7}$ with better performance than clinical practice guidelines. ${ }^{8}$ The effectiveness of prescribing prophylactic aspirin based on preeclampsia early screening has recently been proven, ${ }^{9}$ and even adopted by the International Federation of Gynecology and Obstetrics (FIGO)..$^{10}$

The performance of these tests has been suboptimal in populations other than those that originated the model, ${ }^{11}$ except when the markers have been corrected for the target population. ${ }^{12}$

One of these algorithms, widely distributed because it is free-of-charge, is that of the UK London Fetal Medicine Foundation (FMF) ${ }^{5,6,13}$ Its most recent version, FMF 4.0 (2018), ${ }^{14}$ was released in March 2019, and there are at least 277 registered users in Mexico (https://fetalmedicine.org/lists/map/certified/ Ut), but no Mexican population was included for its creation and neither has any validation been documented on it.

The purpose of this study is to evaluate the performance of the FMF $4.0^{14}$ algorithm in a Mexican population with and without correction for markers.

\section{Materials and methods}

A study was conducted in a cohort of perinatal studies. ${ }^{15}$ Recruitment was from January 2012 to December 2019, and approval by the scientific and bioethical committees of the study site was obtained, adhering to the Declaration of Helsinki of the World Medical Association for medical research involving human subjects.

The inclusion criteria were pregnancy with a single fetus with vitality and crown-rump length (CRL) between 45 and $84 \mathrm{~mm}\left(11^{+1}\right.$ to $14^{+1}$ weeks of gestation), with complete data for the study and with the birth of a phenotypically normal newborn, alive or dead, with at least 24 weeks of gestation or more having been recorded. Pregnancies with chromosomal and non-chromosomal defects, as well as those with spontaneous or induced abortion before 24 weeks were excluded.

\section{Medical history}

It was obtained by self-administered questionnaire, verified by interrogation and operationally coded according to the FMF. ${ }^{16}$

Maternal weight and height were obtained with standard analogue calibrated clinical scale and stadiometer.

Gestational age was established by CRL on ultrasonography according to the Robinson method corrected by Loughna et al..$^{17}$

\section{Mean blood pressure measurement}

Standardized by FMF ${ }^{18}$ and adopted by FIGO, ${ }^{10}$ consistent with current international recommendations, ${ }^{19}$ it required the use of the single medium cuff provided with each device; those of other sizes are not available in the local market and brachial bias correction for maternal weight has been assumed. ${ }^{20}$

The automatic electronic devices were of the Omron $^{\circledR}$ brand (Japan), model HEM-7121, which meets the Food and Drug Administration (FDA) 510(k) requirement. The devices were periodically calibrated. The personnel in charge of the measurements was constantly trained and supervised.

\section{Uterine artery mean pulsatility index measurement}

Voluson (GE Healthcare Technologies ${ }^{\circledR}$ ) ultrasound machines, models E10, E6, S8, 730 Expert, Logiq P5 and Logiq 3 Expert were used; all with multi-frequency transabdominal and transvaginal transducers, under constant preventive maintenance. The exams were carried out by two certified and periodically audited operators (fetalmedicine.org) following standardized methodology. ${ }^{21}$

\section{Pregnancy-associated plasma protein A measurement}

Automated, calibrated and controlled analyzers, based on ultrasensitive and FMF-approved immunoassays, were used, namely: BRAHMS Kryptor compact PLUS (ThermoFisher ${ }^{\circledR}$ ) by time-resolved amplified cryptate emission, Cobas e411 $\left(\right.$ Roche $\left.^{\circledR}\right)$ by 
electrochemiluminescence, and DELFIAXpress $\left(\right.$ PerkinElmer ${ }^{\circledR}$ ) by time-resolved amplified europium emission.

The samples were peripheral venous blood (brachial) serum, with analyte stability ${ }^{22}$ and temporal validity ${ }^{23}$ being ensured.

\section{Outcomes of interest}

The result of each pregnancy was obtained from the birth, death or delivery certificate, clinical record or patient anamnesis when she returned to the center for a new pregnancy. The records of women with pregnancy-associated hypertension were reviewed to classify preeclampsia or non-preeclampsia according to the International Society for the Study of Hypertension in Pregnancy (ISSHP). ${ }^{24}$

\section{Statistical analysis}

The FMF $4.0^{14}$ algorithm was applied, based on the competing risks mode ${ }^{25}$ for preeclampsia. A priori risk was established based on medical history. ${ }^{16}$ The values of each marker were standardized in multiples of the median (MoM) both by the original algorithm ${ }^{14}$ $\left(\mathrm{MoM}_{a}\right)$ and by specific population medians $\left(\mathrm{MoM}_{b}\right)$; these data are in press $(10.6084 / \mathrm{m} 9$. figshare.12268328, 10.6084/m9.figshare.12991322), except for PAPP-A. ${ }^{23,26}$ Expected MoMs configuration $^{13}$ was centered at $<37$ weeks, and the multivariate normal probability density functions of each marker and its combinations (scenarios) were calculated based on the $\log _{10}(\mathrm{MoM})$ of each model and the covariance matrices for each outcome. Likelihood ratios by scenario were obtained from the corresponding probability densities and applied to the a priori risk in order for Bayesian post-test probability to be obtained.

MoM distribution in women without preeclampsia was audited according to FMF criteria (https://fetalmedicine.org/research/audit/). MoM regression lines by weeks of gestation to preeclampsia-associated delivery were compared with the hypothetical model ${ }^{13,14}$ using Student's t-test for coefficients. ${ }^{27}$

Post-test performance by scenarios of each model was evaluated using ROC curves. $^{28}$

As a pilot test, the performance of the American College of Obstetricians and Gynecologists (ACOG) ${ }^{29}$ and the UK National Institute for Excellence in Health and Care $(\mathrm{NICE})^{30}$ guidelines was calculated and plotted.
Representativeness of post-test probabilities of each model was explored by inspection of their calibration curves. ${ }^{31}$

Normality, linearity and homoscedasticity assumptions were tested in order to decide whether to apply parametric or non-parametric statistics or to transform the variables for analysis.

The level of significance was $\alpha=0.05$ for statistical tests (degree of significance [p]).

Sample size was based on both a statistical power ${ }^{32}$ for the minimal area reported under the ROC curve: $0.733^{14}$ (596 observations), and a frequency of $5.4 \%$ for preeclampsia in Mexico City, ${ }^{33}$ and a sensitivity of $65.6 \%$ for the test in a population other than that which originated it; ${ }^{12} n=741$ was calculated ${ }^{32}$ with 40 preeclampsia incidences.

The database was created using the Astraia ${ }^{\circledR}$ (Germany) and Excel $^{\circledR}$ (USA) programs (available upon reasonable request to the corresponding author). Statistical analysis was carried out using the Excel ${ }^{\circledR}$ (USA) and MATLAB ${ }^{\circledR}$ (USA) programs with valid licenses; the programming codes are the property of the laboratory.

\section{Results}

The incidence of preeclampsia was $40 / 807$ (5.0\%; 95\% confidence interval $[\mathrm{Cl}]:$ 3.6-6.3). There were $29 / 40(73 \%)$ births $<37$ weeks due to preeclampsia and 118/767 (15\%) without preeclampsia $(p<0.001$, Fisher's exact test). The characteristics of the sample are shown in table 1.

The distribution of markers in cases without preeclampsia is illustrated in figure 1. Central values of the original model were located beyond \pm 0.2 standard deviations (SD) of hypothetical values:

$$
\begin{aligned}
& \mathrm{MBP}=0.927 \mathrm{MoM}_{a}=-0.9 \mathrm{SD} \\
& \mathrm{mPI}=0.895 \mathrm{MoM}_{a}=-0.4 \mathrm{SD} \\
& \text { PAPP-A }=0.815 \mathrm{MoM}_{a}=0.4 \mathrm{DE}
\end{aligned}
$$

Central values of the corrected ${ }_{b}$ model for local population were within an optimal $\pm 0.1 \mathrm{SD}$ of the hypothetical model:

$$
\begin{aligned}
& M B P=0.991 \mathrm{MoM}_{b}=-0.1 \mathrm{SD} \\
& \mathrm{mPI}=1.030 \mathrm{MoM}_{b}=+0.1 \mathrm{SD} \\
& \text { PAPP-A }=0.963 \mathrm{MoM}_{b}=-0.1 \mathrm{SD} .
\end{aligned}
$$

MoMs distribution by gestational age at delivery due to preeclampsia is depicted in figure 2 with the hypothetical regression lines and those of the sample for both the original ${ }_{a}$ and corrected $d_{b}$ models. The MBP line was parallel $(p=0.226)$ but significantly lower than the hypothetical line in the 
Gaceta Médica de México. 2021;157

Table 1. Maternal and gestational characteristics in the study groups

\begin{tabular}{|c|c|c|c|}
\hline Variables & No preeclampsia & Preeclampsia & p-value \\
\hline Maternal age $\left(\right.$ years) ${ }^{\dagger}$ & $33.0(30.0 ; 35.9)$ & $34.4(31.0 ; 39.0)$ & $0.032^{*}$ \\
\hline Maternal weight $(\mathrm{kg})^{\dagger}$ & $61.4(55.4 ; 68.6)$ & $63.6(58.8 ; 74.2)$ & 0.060 \\
\hline Maternal height $(\mathrm{cm})^{\dagger}$ & $160.0(156.0 ; 164.0)$ & 161.5 (159.0; 164.6) & 0.101 \\
\hline Body mass index ${ }^{\dagger}$ & $23.9(21.8 ; 26.8)$ & $24.0(23.2 ; 39.0)$ & 0.134 \\
\hline Gestational age (weeks) ${ }^{\dagger}$ & $12.7(12.3 ; 13.3)$ & $12.7(12.1 ; 13.2)$ & 0.568 \\
\hline $\begin{array}{l}\text { Ethnicity }{ }^{\ddagger} \\
\text { Caucasian/Hispanic } \\
\text { Afro-Caribbean } \\
\text { South Asian } \\
\text { East Asian } \\
\text { Other, mixed }\end{array}$ & $\begin{array}{l}674(87.9) \\
3(0.4) \\
2(0.3) \\
16(2.1) \\
72(9.4)\end{array}$ & $\begin{array}{c}34(85.0) \\
0(0.0) \\
0(0.0) \\
0(0.0) \\
6(15.0)\end{array}$ & $\begin{array}{l}0.619 \\
1.000 \\
1.000 \\
1.000 \\
0.265\end{array}$ \\
\hline $\begin{array}{l}\text { Conception } \ddagger \\
\text { Spontaneous } \\
\text { In vitro fertilization } \\
\text { Ovulation inducer drugs }\end{array}$ & $\begin{array}{c}686(89.4) \\
46(6.0) \\
35(4.6)\end{array}$ & $\begin{array}{c}31(77.5) \\
9(22.5) \\
0(0.0)\end{array}$ & $\begin{array}{l}0.034^{*} \\
0.001^{*} \\
0.410\end{array}$ \\
\hline $\begin{array}{l}\text { Smoking habit }{ }^{\ddagger} \\
\text { Smoker } \\
\text { Former smoker } \\
\text { Non-smoker }\end{array}$ & $\begin{array}{c}16(2.1) \\
83(10.8) \\
668(87.1)\end{array}$ & $\begin{array}{c}1(2.5) \\
4(10.0) \\
35(87.5)\end{array}$ & $\begin{array}{l}0.582 \\
1.000 \\
1.000\end{array}$ \\
\hline $\begin{array}{l}\text { Parity } \ddagger \\
\text { Nulliparous } \\
\text { Parity without PE } \\
\text { Parity with previous PE }\end{array}$ & $\begin{array}{c}562(73.3) \\
195(25.4) \\
10(1.3)\end{array}$ & $\begin{array}{c}32(80.0) \\
1(2.5) \\
7(17.5)\end{array}$ & $\begin{aligned} & 0.462 \\
< & 0.001^{*} \\
< & 0.001^{*}\end{aligned}$ \\
\hline $\begin{array}{l}\text { Medical history } \ddagger \S \\
\text { Chronic hypertension } \\
\text { Systemic lupus erythematosus } \\
\text { Anti-phospholipid syndrome } \\
\text { Family history of } \mathrm{PE}^{\ddagger}\end{array}$ & $\begin{array}{l}6(0.8) \\
1(0.1) \\
6(0.8) \\
9(1.2)\end{array}$ & $\begin{array}{l}2(5.0) \\
0(0.0) \\
0(0.0) \\
4(10.0)\end{array}$ & $\begin{array}{l}0.056 \\
1.000 \\
0.003^{*}\end{array}$ \\
\hline
\end{tabular}

Comparisons between study groups were made using the chi-square test or Fisher's exact test for categorical variables and Mann-Whitney's U-test for continuous variables. *Statistically significant.

${ }^{\dagger}$ Median (IQR).

$\neq n(\%)$.

sThere were no pregnant women with diabetes mellitus in any of the study groups.

PE: preeclampsia.
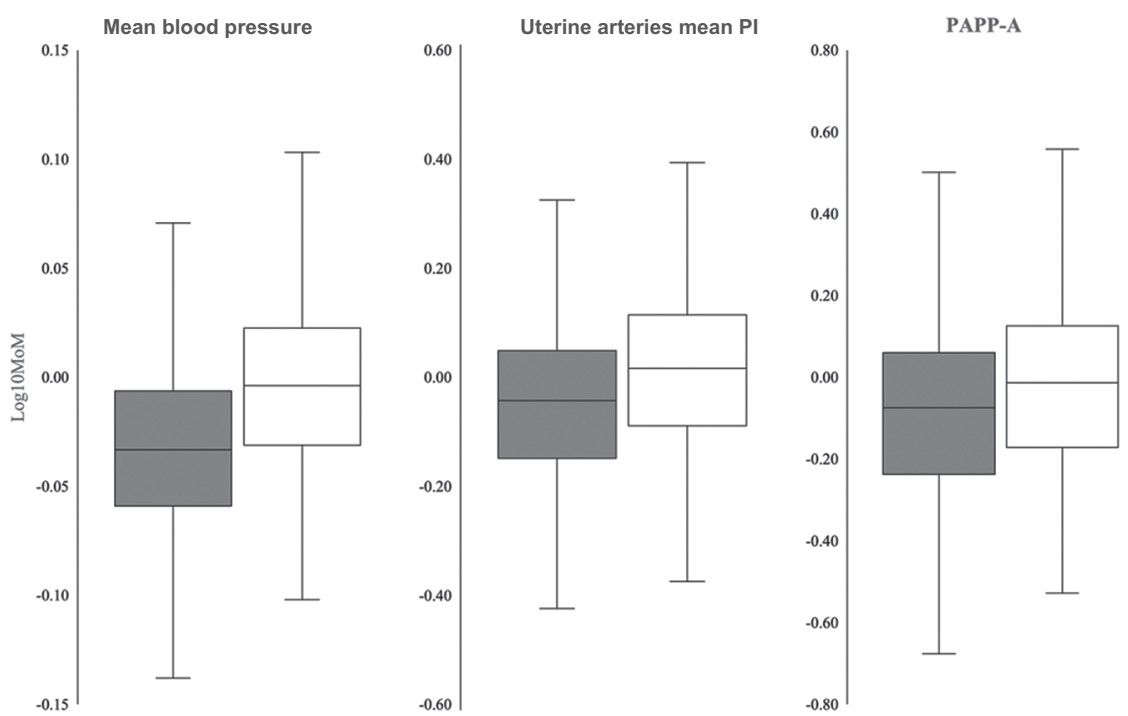

Figure 1. Distribution of multiples of the median (MoM) of the markers transformed into base 10 log within the group without preeclampsia $(n=767) ;$ in box-and-whiskers plots, the original model/4 and local population-corrected model (white box); all pairs were significantly different $(p<0.001$, Student's $t$-test).

PI: pulsatility index; PAPP-A: pregnancy-associated plasma protein $A$. 

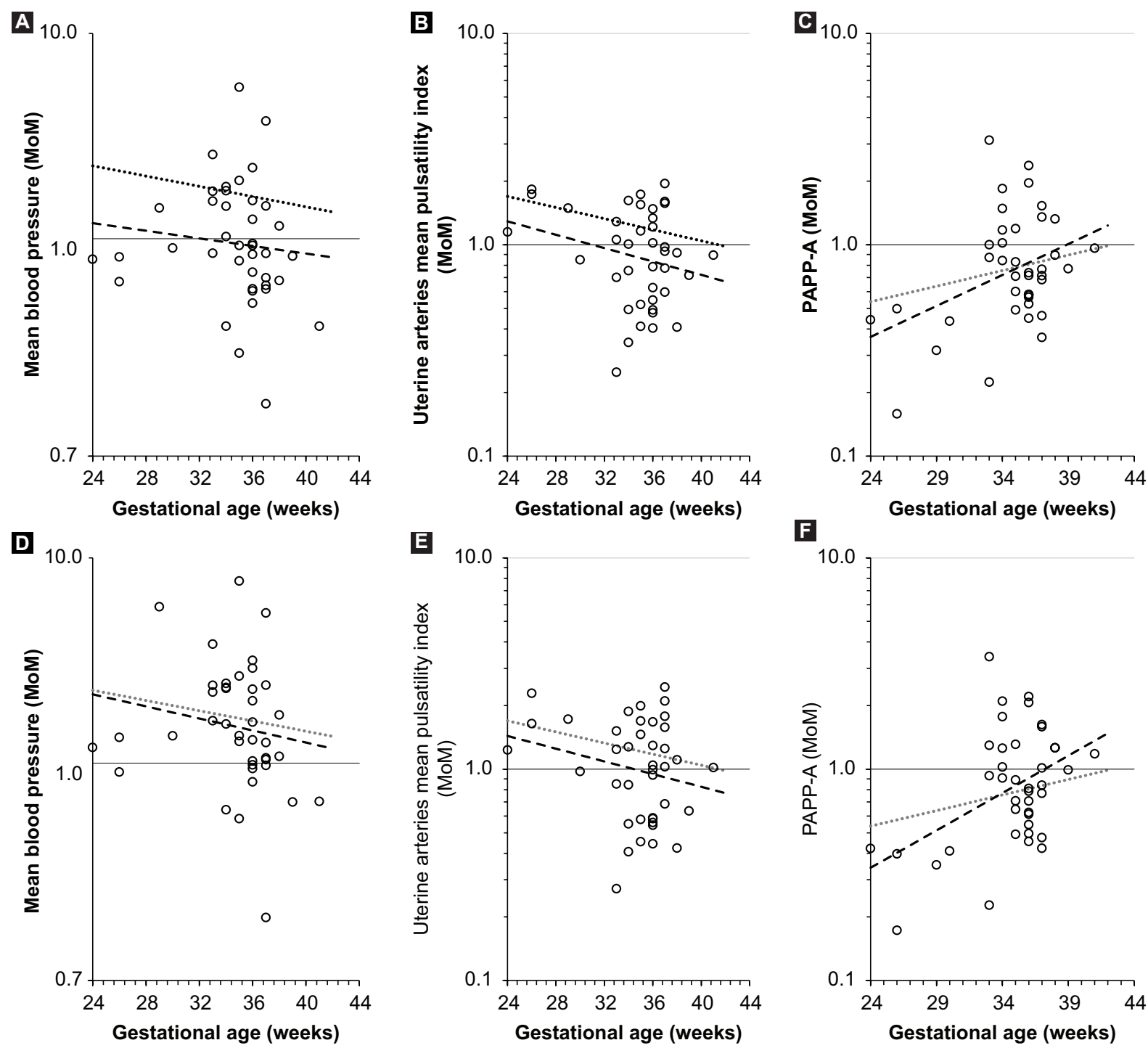

Figure 2. Distribution of multiples of the median (MoM) by gestational age at birth due to preeclampsia (o). Regression line of the sample (- -) vs. hypothetical line ${ }^{13}$ (․). The horizontal line (-) refers to $1.0 \mathrm{MoM}$. The original MoM model in upper panel (A, B and C); the population-corrected model in lower panel (D, E and F).

PAPP-A: pregnancy-associated plasma protein A.

original $_{a}$ model $(\mathrm{p}=0.001)$; in contrast, the corrected model line was not significantly different from the hypothetical line (slope $p=0.406$ and intersection $p=0.744$ ). Uterine arteries mean PI line in the original ${ }_{a}$ model showed a steeper slope that was statistically marginal $(p=0.062)$; but not its intersection $(p=0.318)$. In the uterine arteries mean PI corrected model, no significant difference was found (slope $p=0.188$ and intersection $p=0.617$ ). PAPP-A lines in both models were significantly different in terms of slope and intersection $(p<0.001)$.

The ROC curves by marker and their combinations are illustrated in figure 3 both for preeclampsia <
37 weeks and for global preeclampsia; each model separately with the $\mathrm{ACOG}^{29}$ and $\mathrm{NICE}^{30}$ criteria comparative pilot test. Relevant ROC curves cutoff points are shown in table 2.

Total combined test calibration lines, for each model separately, are illustrated in figure 4.

\section{Discussion}

Until now, there was no information on the performance of the FMF $4.0^{14}$ algorithm in our country. Analysis by markers and their combinations is particularly valuable, given that their availability varies in our institutions. 

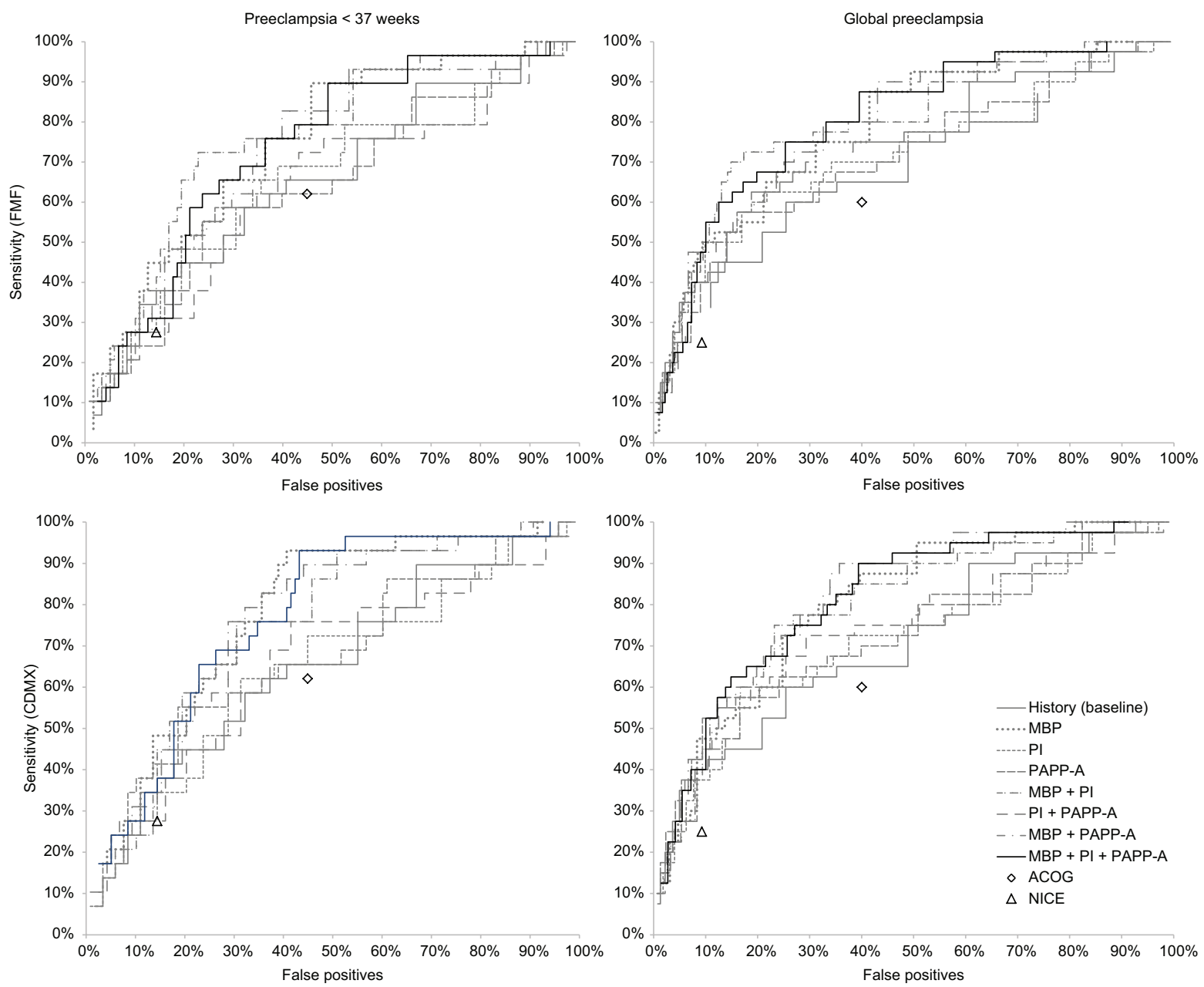

Figure 3. ROC curves for preeclampsia < 37 weeks (left) and global preeclampsia (right), original model ${ }^{14}$ and model corrected for local Mexican population (bottom). MBP: mean blood pressure; Pl: uterine arteries mean pulsatility index; PAPP-A: pregnancy-associated plasma protein A; ACOG: American College of Obstetricians and Gynecologists; ${ }^{29}$ NICE: UK National Institute for Health and Care Excellence. ${ }^{30}$

Another key contribution of our study was to prove that the original ${ }_{a}$ FMF- $2018^{14}$ medians model of the algorithm under study is not valid for our population. The authors advise against the use of this calculator in Mexico without correction for population, unless it is temporary (see below). Correction for biochemical markers is possible in first-trimester aneuploidy screening computer packages, ${ }^{26}$ but not for MBP or uterine arteries mean PI. We have chosen to generate

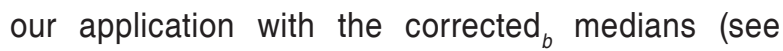
above); its external validity will be limited by the standardization of processes and regional differences in the country.

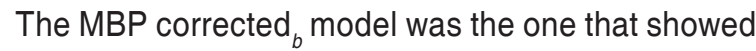
the best reproducibility with regard to what was expected $^{13}$ and to what has been reported by others. ${ }^{12}$
Given this validity demonstration and the simplicity of the method, this line of research should be expanded.

The corrected ${ }_{b}$ PAPP-A model had a steeper-than-expected slope towards very early preeclampsia; ${ }^{13}$ given that the correction was with a different methodology than that for MBP, investigating the development of a local model is justified.

The FMF $4.0^{14}$ version does not have a predetermined cutoff point, leaving this decision to the end user. A useful contribution of our study was the ROC characteristic, which allows selecting the cutoff point by scenario and according to the goals in centers similar to ours. Based on the ROC table, it can even be proposed, as a temporary solution to the lack of 
Table 2. Performance of the markers for preeclampsia $<37$ weeks and global preeclampsia and their combinations according to the original model ${ }^{14}$ and local population-corrected model

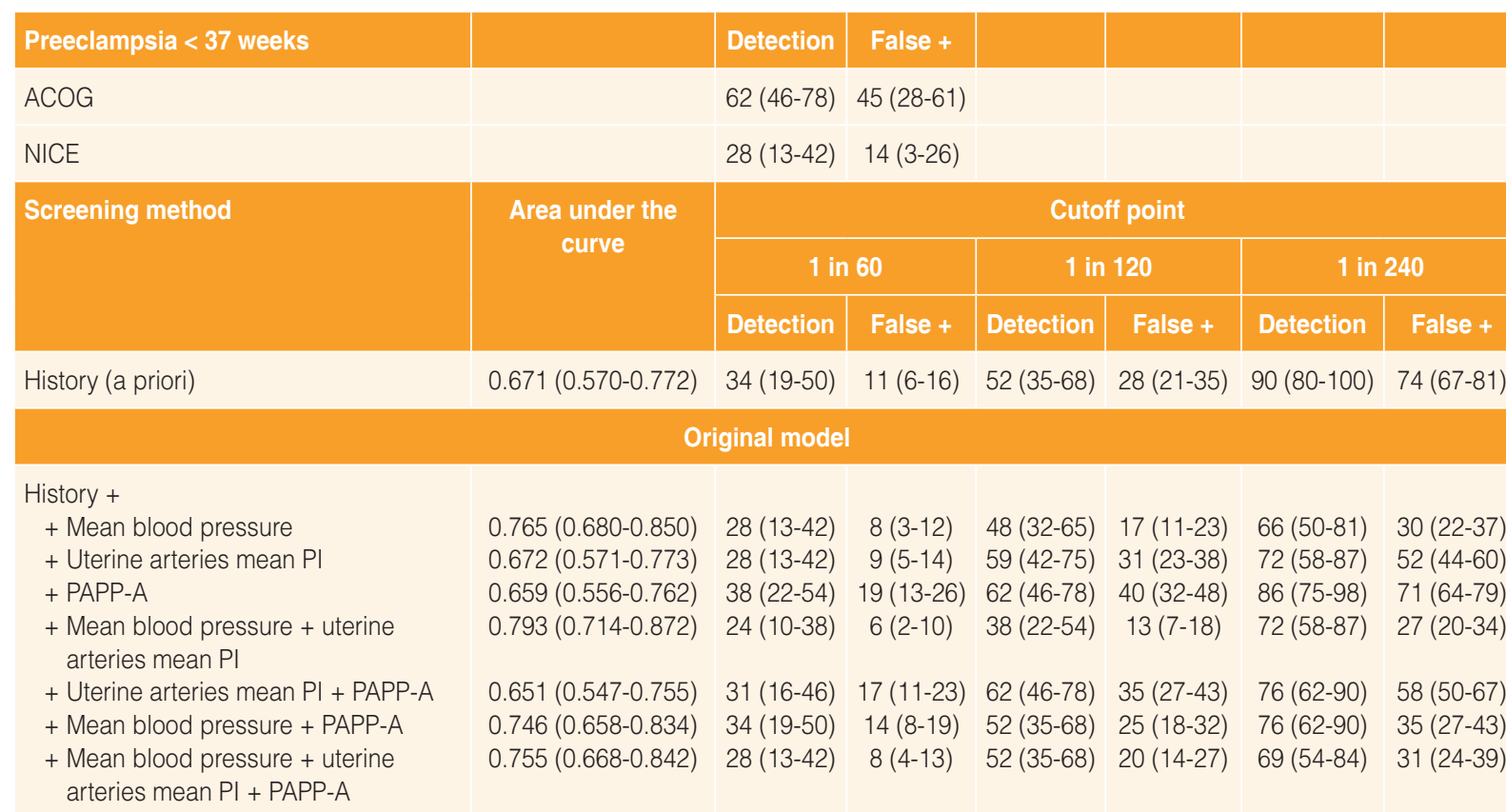

\section{Population-corrected model}

History +

+ Mean blood pressure

+ Uterine arteries mean PI

+ PAPP-A

+ Mean blood pressure + uterine arteries mean PI

+ Uterine arteries mean PI + PAPP-A

+ Mean blood pressure + PAPP-A

+ Mean blood pressure + uterine arteries mean PI + PAPP-A
$0.765(0.680-0.850) \quad 45(28-61) \quad 15(9-21) \quad 59(42-75) \quad 25(18-33) \quad 90(80-100) \quad 47(39-56)$ $0.660(0.557-0.763) \quad 34(19-50) \quad 14(9-20) \quad 62(46-78) \quad 38(30-46) \quad 76(62-90) \quad 60(52-68)$ $0.695(0.598-0.792) \quad 38(22-54) \quad 10(5-15) \quad 59(42-75) \quad 33(25-41) \quad 86(75-98) \quad 68(60-75)$ $0.784(0.704-0.864) \quad 45(28-61) \quad 14(9-20) \quad 72(58-87) \quad 31(23-38) \quad 86(75-98) \quad 46(38-54)$ $0.676(0.576-0.776) \quad 38(22-54) \quad 16(10-22) \quad 69(54-84) \quad 37(29-45) \quad 79(66-93) \quad 59(51-67)$ $0.777(0.695-0.859) \quad 48(32-65) \quad 18(12-24) \quad 66(50-81) \quad 26(19-33) \quad 93(85-100) \quad 49(41-57)$ $0.785(0.705-0.865) \quad 52(35-68) \quad 18(12-24) \quad 69(54-84) \quad 29(21-36) \quad 93(85-100) \quad 43(35-51)$
Global preeclampsia

$A C O G$

NICE

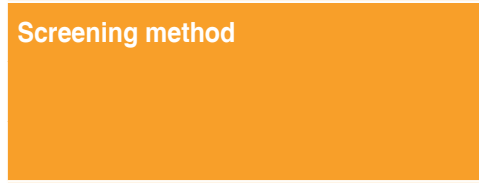

History (a priori)

\section{Detection False +}

$60(44-76) \quad 40(24-56)$

$25(11-39) \quad 9(0-19)$

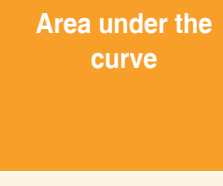

\begin{tabular}{|c|c|c|c|c|c|}
\hline \multicolumn{6}{|c|}{ Cutoff point } \\
\hline \multicolumn{2}{|c|}{1 in 60} & \multicolumn{2}{|c|}{1 in 120} & \multicolumn{2}{|c|}{1 in 240} \\
\hline Detection & False + & Detection & False + & Detection & False + \\
\hline
\end{tabular}

$0.726(0.659-0.793) \quad 35(22-48) \quad 5(4-6) \quad 53(38-67) \quad 21(18-23) \quad 93(85-100) \quad 69(67-72)$

\section{Original model}

History +

+ Mean blood pressure

+ Uterine arteries mean PI

+ PAPP-A

+ Mean blood pressure + uterine arteries mean $\mathrm{PI}$

+ Uterine arteries mean PI + PAPP-A

+ Mean blood pressure + PAPP-A

+ Mean blood pressure + uterine arteries mean PI + PAPP-A

\begin{tabular}{|c|c|c|c|c|c|c|}
$0.801(0.747-0.855)$ & $30(17-43)$ & $4(3-5)$ & $50(36-64)$ & $9(8-11)$ & $65(52-78)$ & $23(20-26)$ \\
$0.737(0.671-0.803)$ & $33(19-46)$ & $5(4-7)$ & $58(44-71)$ & $17(15-19)$ & $73(60-85)$ & $46(43-49)$ \\
$0.732(0.666-0.798)$ & $40(26-54)$ & $9(7-11)$ & $60(46-74)$ & $27(24-30)$ & $85(75-95)$ & $64(61-67)$ \\
$0.887(0.852-0.922)$ & $20(9-31)$ & $3(2-4)$ & $43(29-56)$ & $8(6-10)$ & $70(57-83)$ & $17(15-19)$ \\
& & & & & & \\
$0.742(0.677-0.807)$ & $33(19-46)$ & $8(6-10)$ & $63(49-76)$ & $22(19-24)$ & $78(66-89)$ & $50(46-53)$ \\
$0.799(0.745-0.853)$ & $35(22-48)$ & $5(4-7)$ & $50(36-64)$ & $13(11-15)$ & $73(60-85)$ & $27(24-30)$ \\
$0.821(0.771-0.871)$ & $23(11-34)$ & $4(3-5)$ & $55(41-69)$ & $10(8-12)$ & $68(54-81)$ & $20(18-23)$
\end{tabular}

(Continued) 
Table 2. Performance of the markers for preeclampsia $<37$ weeks and global preeclampsia and their combinations according to the original model ${ }^{14}$ and local population-corrected model (Continued)

\begin{tabular}{|c|c|c|c|c|c|c|c|}
\hline \multicolumn{8}{|c|}{ Population-corrected model } \\
\hline History + & & & & & & & \\
\hline + Mean blood pressure & $0.808(0.756-0.860)$ & $48(33-62)$ & $8(7-10)$ & $60(46-74)$ & $20(18-23)$ & $88(78-97)$ & $43(40-46)$ \\
\hline + Uterine arteries mean PI & $0.728(0.661-0.795)$ & $38(24-51)$ & $8(6-9)$ & $60(46-74)$ & $26(23-29)$ & $80(69-91)$ & $57(54-61)$ \\
\hline + PAPP-A & $0.747(0.683-0.822)$ & $38(24-51)$ & $5(4-7)$ & $58(44-71)$ & $20(18-23)$ & $83(72-93)$ & $61(58-64)$ \\
\hline $\begin{array}{l}+ \text { Mean blood pressure + uterine } \\
\text { arteries mean PI }\end{array}$ & $0.812(0.760-0.864)$ & $45(31-59)$ & $9(8-11)$ & $68(54-81)$ & $21(18-24)$ & $85(75-95)$ & $40(37-43)$ \\
\hline + Uterine arteries mean PI + PAPP-A & $0.747(0.683-0.811)$ & $40(26-54)$ & $8(7-10)$ & $68(54-81)$ & $25(23-28)$ & $80(69-91)$ & $54(51-57)$ \\
\hline + Mean blood pressure + PAPP-A & $0.825(0.776-0.874)$ & $45(31-59)$ & $9(7-11)$ & $65(52-78)$ & $20(17-22)$ & $90(82-98)$ & $42(38-45)$ \\
\hline $\begin{array}{l}\text { + Mean blood pressure }+ \text { uterine } \\
\text { arteries mean PI + PAPP-A }\end{array}$ & $0.823(0.752-0.894)$ & $53(38-67)$ & $10(8-12)$ & $65(52-78)$ & $20(17-22)$ & $90(82-98)$ & $39(36-43)$ \\
\hline
\end{tabular}
protein A.
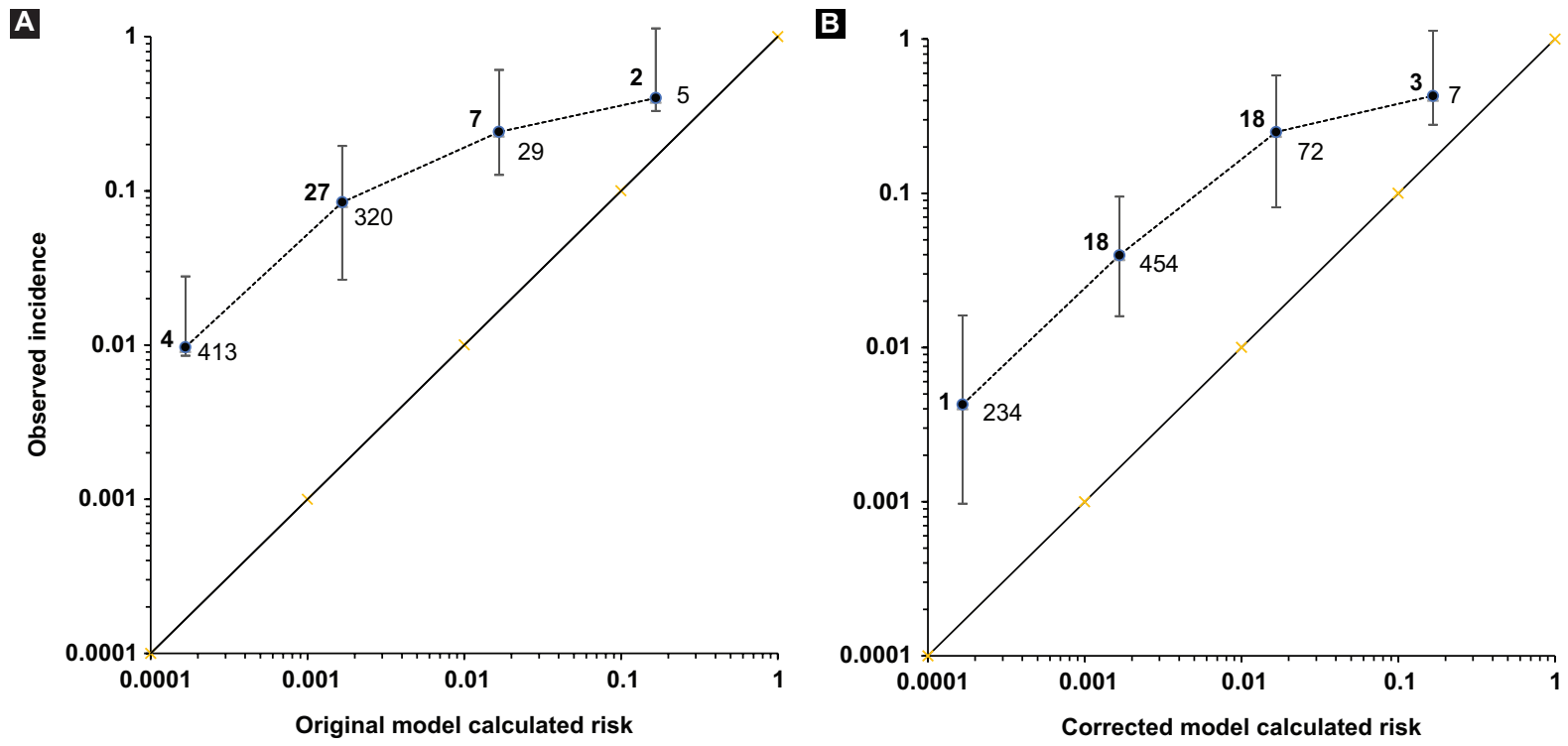

Figure 4. Calibration curves for preeclampsia < 37 weeks combined screening. Calibration lines (- -) for preeclampsia screening by history + mean blood pressure + uterine arteries mean pulsatility index + pregnancy-associated plasma protein A: original model ${ }^{14}(\mathbf{A})$ and corrected model (B) for multiples of the median (MoM) of Mexican local population (right). The diagonal line indicates the ideal scenario.

correction for population, a higher cutoff point for each scenario.

The comparative pilot test with $\mathrm{ACOG}^{29}$ and $\mathrm{NICE}^{30}$ guidelines vs. multivariate Bayesian model was similar to findings reported by others, with lower performance than the FMF ${ }^{11}$ algorithm, but specific research on the subjects is required.

Sample characteristics, false positive rates and the calibration curve are consistent with sample bias for high-risk pregnancies. The study design was based on the competing risks model; 25,34 therefore, preeclampsia-free births were not necessarily normal, had various medical or obstetric indications, with up to $15 \%$ of prematurity observed in this sample of a larger cohort. This explains higher false positive rates for the expected detection rates of the test; ${ }^{12-14}$ thus, population composition should also be considered for selecting practical cutoff points.

An essential achievement of our study was the programming code that was specifically created, as a result of the theoretical and practical mastery of the algorithm. With this and the follow-up of the cohort, generating a local competing risks model for preeclampsia and other adverse perinatal outcomes will be possible. 


\section{Conclusions}

The use of the FMF $4.0^{14}$ calculator in Mexico without correction for target population markers is advised against. Coding an application with local medians and, better yet, developing an own competing risks model for preeclampsia is recommended.

\section{Acknowledgments}

The authors thank the work teams at Medical Center for Specialized Fetal Care and Laboratorio CEMAFE S.A. de C.V.

\section{Funding}

This research has not received any specific grant from agencies of the public, commercial or non-profit sectors.

\section{Conflict of interests}

The authors declare that they have no conflicts of interest.

\section{Ethical disclosures}

Protection of human and animal subjects. The authors declare that no experiments were performed on humans or animals for this research.

Confidentiality of data. The authors declare that they have followed the protocols of their work center on the publication of patient data.

Right to privacy and informed consent. The authors declare that no patient data appear in this article.

\section{References}

1. Duley L. The global impact of pre-eclampsia and eclampsia. Semin Perinatol. 2009;33:130-7.

2. Evaluación Estratégica sobre Mortalidad Materna en México 2010: características sociodemográficas que obstaculizan a las mujeres embarazadas su acceso efectivo a instituciones de salud. Mexico, Mexico City: CONEVAL; 2012

3. Bujold E, Roberge S, Lacasse Y, Bureau M, Audibert F, Marcoux S, et al. Prevention of preeclampsia and intrauterine growth restriction with aspirin started in early pregnancy: a meta-analysis. Obstet Gynecol. 2010;116:402-14.

4. Al-Rubaie ZTA, Askie LM, Hudson HM, Ray JG, Jenkins G, Lord SJ. Assessment of NICE and USPSTF guidelines for identifying women at high risk of pre-eclampsia for tailoring aspirin prophylaxis in pregnancy: An individual participant data meta-analysis. Eur J Obstet Gynecol Reprod Biol. 2018:229:159-66.

5. Poon LC, Kametas NA, Maiz N, Akolekar R, Nicolaides KH. First-trimester prediction of hypertensive disorders in pregnancy. Hypertension. 2009;53:812-8.
6. Akolekar R, Syngelaki A, Poon L, Wright D, Nicolaides KH. Competing risks model in early screening for preeclampsia by biophysical and biochemical markers. Fetal Diagn Ther. 2013;33:8-15.

7. Crovetto F, Figueras F, Triunfo S, Crispi F, Rodríguez-Sureda V, Peguero A, et al. Added value of angiogenic factors for the prediction of early and late preeclampsia in the first trimester of pregnancy. Fetal Diagn Ther. 2014;35:258-66.

8. O'Gorman N, Wright D, Poon LC, Rolnik DL, Syngelaki A, de Alvarado M, et al. Multicenter screening for pre-eclampsia by maternal factors and biomarkers at 11-13 weeks' gestation: comparison with NICE guidelines and ACOG recommendations. Ultrasound Obstet Gynecol. 2017:49:756-60.

9. Rolnik DL, Wright D, Poon LC, O'Gorman N, Syngelaki A, de Paco Matallana C, et al. Aspirin versus placebo in pregnancies at high risk for preterm preeclampsia. N Engl J Med. 2017;377:613-22.

10. Poon LC, Shennan A, Hyett JA, Kapur A, Hadar E, Divakar H, et al. The International Federation of Gynecology and Obstetrics (FIGO) initiative on pre-eclampsia: A pragmatic guide for first-trimester screening and prevention. Int J Gynecol Obstet. 2019:145:1-33.

11. Oliveira N, Magder LS, Blitzer MG, Baschat AA. First-trimester prediction of pre-eclampsia: external validity of algorithms in a prospectively enrolled cohort. Ultrasound Obstet Gynecol. 2014;44:279-85.

12. Chaemsaithong $P$, Pooh RK, Zheng M, Ma R, Chaiyasit N, Tokunaka M, et al. Prospective evaluation of screening performance of first-trimester prediction models for preterm preeclampsia in an Asian population. Am J Obst Gynecol. 2019;221:650.e1-e16.

13. O'Gorman N, Wright D, Syngelaki A, Akolekar R, Wright A, Poon LC, et al. Competing risks model in screening for preeclampsia by maternal factors and biomarkers at 11-13 weeks gestation. Am J Obst Gynecol. 2016;214:103.e1-e12.

14. Tan MY, Syngelaki A, Poon LC, Rolnik DL, O'Gorman N, Delgado JL, et al. Screening for pre-eclampsia by maternal factors and biomarkers at 11-13 weeks' gestation. Ultrasound Obstet Gynecol. 2018;52:186-95.

15. Oviedo-Cruz H, Hernández-Paredez J, Ruiz-Ramírez AV. Tamiz prenatal de aneuploidías en el primer trimestre: auditoria a un centro de medicina fetal con laboratorio especializado en México. Ginecol Obstet Mex. 2015;83:259-76

16. Wright D, Syngelaki A, Akolekar R, Poon LC, Nicolaides KH. Competing risks model in screening for preeclampsia by maternal characteristics and medical history. Am J Obstet Gynecol. 2015;213:62 e1-e10.

17. Loughna P, Chitty L, Evans T, Chudleigh T. Fetal size and dating: Charts recommended for clinical obstetric practice. Ultrasound. 2009;17:160-6.

18. Poon LCY, Zymeri NA, Zamprakou A, Syngelaki A, Nicolaides KH. Protocol for measurement of mean arterial pressure at 11-13 weeks' gestation. Fetal Diagn Ther. 2012;31:42-8.

19. Unger T, Borghi C, Charchar F, Khan NA, Poulter NR, Prabhakaran D, et al. 2020 International Society of Hypertension Global Hypertension Practice Guidelines. Hypertension. 2020;75:1334-57.

20. Ng CM, Badon SE, Dhivyalosini M, Hamid JJM, Rohana AJ, Teoh AN, et al. Associations of pre-pregnancy body mass index, middle-upper arm circumference, and gestational weight gain. Sex Reprod Healthc. 2019;20:60-5.

21. Gómez O, Fiqueras F, Fernández S, Bennasar M, Martínez JM, Puerto $\mathrm{B}$, et al. Reference ranges for uterine artery mean pulsatility index at 11-41 weeks of gestation. Ultrasound Obstet Gynecol. 2008:32:128-32.

22. Cruz J, Cruz G, Minekawa R, Maiz N, Nicolaides KH. Effect of temperature on free beta-human chorionic gonadotropin and pregnancy-associated plasma protein-A concentration. Ultrasound Obstet Gynecol. 2010;36:141-6.

23. Wright D, Spencer K, Kagan KK, Torring N, Petersen OB, Christou A, et al. First-trimester combined screening for trisomy 21 at 7-14 weeks' gestation. Ultrasound Obstet Gynecol. 2010;36:404-11.

24. Brown MA, Magee LA, Kenny LC, Karumanchi SA, McCarthy FP, Saito $S$, et al. The hypertensive disorders of pregnancy: ISSHP classification, diagnosis \& management recommendations for international practice. Pregnancy Hypertens. 2018;13:291-310.

25. Kalbfleisch JD, Prentice RL. Competing risks and multistate models. En: Kalbfleisch JD, Prentice RL, editores. The statistical analysis of failure time data. $2^{\text {nd }}$ Ed. Hoboken, New Jersey, USA: John Wiley \& Sons; 2002. pp. 247-77.

26. Oviedo-Cruz H, Reyes-Mendoza M, Mestizo-Reyes V. Corrección de medianas de la fracción beta libre de gonadotrofina coriónica humana y proteína plasmática A del embarazo del primer trimestre para una muestra de población mexicana. Ginecol Obstet Mex. 2017;85:787-98.

27. Andrade JM, Estévez-Pérez MG. Statistical comparison of the slopes of two regression lines: A tutorial. Anal Chim Acta. 2014;838:1-12.

28. Steyerberg EW, Vickers AJ, Cook NR, Gerds T, Gonen M, Obuchowski N, et al. Assessing the performance of prediction models: a framework for traditional and novel measures. Epidemiology. 2010;21:128-38.

29. ACOG Practice Bulletin No. 202: Gestational hypertension and preeclampsia. Obstet Gynecol. 2019;133:e1-e25. 
30. National Guideline Alliance (UK). Hypertension in pregnancy: diagnosis and management. London: National Institute for Health and Care Excellence (UK); June 2019.

31. Wright D, Tan MY, O'Gorman N, Poon LC, Syngelaki A, Wright A et al. Predictive performance of the competing risk model in screening for preeclampsia. Am J Obstet Gynecol. 2019;220:199. e1-e13.
32. Hajian-Tilaki K. Sample size estimation in diagnostic test studies of biomedical informatics. J Biomed Inform. 2014:48:193-204.

33. Cerón M Harlow Sánchez C, Núñez RM. Risk factors for pre-eclampsia/ eclampsia among working women in Mexico City. Paediatr Perinat Epidemiol. 2001;15:40-6.

34. Wright D, Akolekar R, Syngelaki A, Poon LC, Nicolaides KH. A competing risks model in early screening for preeclampsia. Fetal Diagn Ther. 2012;32:171-8. 